\title{
NOTES
}

\section{Trienomycin G, a New Inhibitor of Nitric Oxide Production in Microglia Cells, from Streptomyces sp. 91614}

\author{
WON-Gon KIM, NAN-KYU Song and ICK-Dong YoO* \\ Korea Research Institute of Bioscience and Biotechnology, \\ P. O. Box 115, Yusong, Taejon 305-600, Korea
}

(Received for publication August 16, 2001)

Nitric oxide (NO) plays an important role in the physiology and pathophysiology of the central nervous, cardiovascular, and immune systems ${ }^{1 \sim 3)}$. NO is produced by the oxidation of L-arginine to L-citrulline by one of three isoenzymes of nitric oxide synthase (NOS): neuronal (nNOS), endothelial (eNOS), and inducible (iNOS) ${ }^{4,5}$. iNOS produces higher levels of NO which plays a role in host defence mechanisms but is also implicated in the pathogenesis of various inflammatory diseases such as septic shock, rheumatoid arthritis, inflammatory bowel disease, and neurodegenerative diseases ${ }^{6 \sim 8)}$. Activation of microglia is a histopathological hallmark of neurodegenerative diseases including post-ischemic stroke, Alzheimer's disease, Parkinson's disease, multiple sclerosis, and the AIDS dementia complex ${ }^{9 \sim 11}$. Microglia activation

Fig. 1. Structures of trienomycin G (1) and trienomycin A (2).

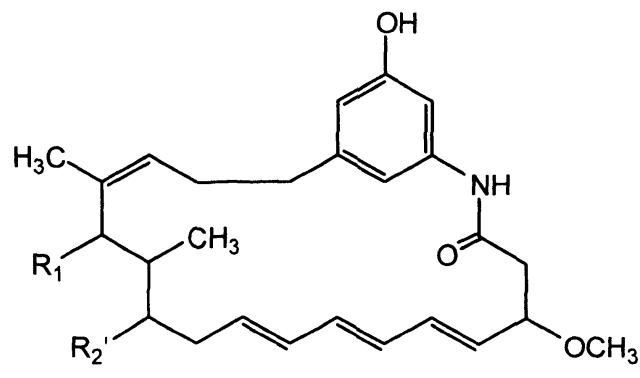

$$
\begin{array}{ll}
1 \mathrm{R}_{1}=\mathrm{R}, & \mathrm{R}_{2}=\mathrm{OH} \\
2 \mathrm{R}_{1}=\mathrm{OH}, & \mathrm{R}_{2}=\mathrm{R}
\end{array}
$$

Table 1. Physico-chemical property of 1 .

\begin{tabular}{ll}
\hline Appearance & white powder \\
{$[\alpha]_{\mathrm{D}}$} & $+53(c 0.6, \mathrm{MeOH})$ \\
ESI-MS $(m / z)$ & $623(\mathrm{M}+\mathrm{H})^{+}$ \\
HRESI-MS $(m / z)$ & \\
$\quad$ found & 623.3794 \\
$\quad$ calcd. & 623.3696 \\
Molecular formula & $\mathrm{C}_{36} \mathrm{H}_{50} \mathrm{~N}_{2} \mathrm{O}_{7}$ \\
$\mathrm{UV} \lambda_{\text {max }}$ nm $(\log \varepsilon)(\mathrm{MeOH})$ & $250(4.16), 262(4.17), 271(4.24)$, \\
& $283(4.13)$ \\
IR $(\mathrm{KBr}) \gamma \mathrm{cm}^{-1}$ & $3312,2927,1730,1654,1549$, \\
& 1449,1096 \\
TLC $(\mathrm{Rf})^{\mathrm{a}}$ & 0.32 \\
$\mathrm{HPLC}\left(\mathrm{R}_{\mathrm{t}}\right)^{\mathrm{b}}$ (minute) & 20 \\
\hline
\end{tabular}

${ }^{\mathrm{a}}$ Silica gel TLC (Kieselgel 60F 254 , Merck); solvent, $\mathrm{CHCl}_{3}-\mathrm{MeOH}(10: 1)$.

${ }^{\mathrm{b}}$ Column, Cosmosil $\mathrm{C}_{18}$ (4.6 x $\left.150 \mathrm{~mm}\right)$; solvent, $\mathrm{CH}_{3} \mathrm{CN}-\mathrm{H}_{2} \mathrm{O}$ (50:50);

flow rate, $0.5 \mathrm{ml} / \mathrm{min}$; UV absorbance at $280 \mathrm{~nm}$. 
is believed to contribute to neurodegenerative processes through the release of various pro-inflammatory cytokines and the overproduction of $\mathrm{NO}^{12 \sim 14)}$. In this respect, an inhibitor of NO production in microglia cells may be a potential therapeutic agent for intervention of various inflammatory and neurodegenerative disease ${ }^{15,16)}$. Vineomycin $\mathrm{C}$ has been isolated as the inhibitor of iNOS from microbial metabolites ${ }^{17}$. In the course of our screening for inhibitors of $\mathrm{NO}$ production in $\mathrm{BV}-2$ microglia cells, we isolated a new potent compound named trienomycin $G$ (1) from a fermentation broth of Streptomyces sp. 91614 (Fig. 1). In addition, the related known compound, trienomycin $\mathrm{A}^{18)}(2)$, was also detected in the same culture broth. We report here the fermentation, isolation, physico-chemical properties, structure determination, and biological activities of $\mathbf{1}$.

The producing strain G91614 was isolated from a soil sample collected in Taejon-city, Chungcheongnam-do, Korea and assigned to the Streptomyces sp. Fermentation was carried out in 1-liter Erlenmeyer flasks containing soluble starch $1 \%$, glucose $2 \%$, soybean meal $2.5 \%$, beef extract $0.1 \%$, yeast extract $0.4 \%, \mathrm{NaCl} 0.2 \%, \mathrm{~K}_{2} \mathrm{HPO}_{4}$ $0.025 \%$, and $\mathrm{CaCO}_{3} 0.2 \%$ (adjusted to $\mathrm{pH} 7.2$ before sterilization). A piece of strain G91614 from a mature plate culture was inoculated into a $500 \mathrm{ml}$ Erlenmeyer flask containing $80 \mathrm{ml}$ of sterile seed liquid medium with the above composition and cultured on a rotary shaker $(150 \mathrm{rpm})$ at $28^{\circ} \mathrm{C}$ for 3 days. For the production of $1,5 \mathrm{ml}$ of the seed culture was transferred into one-liter Erlenmeyer flasks (35 flasks) containing $150 \mathrm{ml}$ of the above medium, and cultivated for 6 days using the same conditions. The culture supernatant obtained from the culture broth (5 liters) was extracted with an equal volume of EtOAc three times and the EtOAc layer was concentrated in vacuo. The resultant residue was subjected to $\mathrm{SiO}_{2}$ (Merck Art No. 7734.9025) column chromatography followed by elution with $\mathrm{CHCl}_{3}-\mathrm{MeOH}(15: 1)$. The active fractions were pooled and concentrated in vacuo to give an oily residue. The residue was applied again to a Sephadex LH-20 and then eluted with $\mathrm{MeOH}$. Active fraction dissolved in $\mathrm{MeOH}$ was further purified by reverse phase HPLC column $\left(20 \times 250 \mathrm{~mm}, \mathrm{YMC}_{18}\right)$ chromatography with a photodiode array detector. The column was eluted with $\mathrm{CH}_{3} \mathrm{CN}-\mathrm{H}_{2} \mathrm{O}(60: 40)$ at a flow rate of $7 \mathrm{ml} / \mathrm{minute}$ to afford $2(5.6 \mathrm{mg})$ and $1(3.3 \mathrm{mg})$ at a retention time of 16 and 21 minutes, respectively, as white powder.

The physico-chemical properties of $\mathbf{1}$ are summarized in Table 1. It is soluble in methanol, dimethlylsulfoxide and $\mathrm{CHCl}_{3}$, and insoluble in water, ether and $n$-hexane. After TLC on silica gel $60 \mathrm{~F}_{254}$ (Merck) with $\mathrm{CHCl}_{3}-\mathrm{MeOH}$
(10:1), 1 showed an Rf value of 0.32 whereas 2 had an $\mathrm{Rf}$ value of 0.34 . The UV spectrum showed absorption maxima at 250,262, 271, and $283 \mathrm{~nm}$ which was almost same as that of 2 . In the IR spectrum, the absorption bands attributable to an triene $\left(1096 \mathrm{~cm}^{-1}\right)$, an amide (1654 $\left.\mathrm{cm}^{-1}\right)$, an ester $\left(1730 \mathrm{~cm}^{-1}\right)$, and NH or $\mathrm{OH}\left(3312 \mathrm{~cm}^{-1}\right)$ were observed.

The molecular formula of $\mathbf{1}$ was determined to be $\mathrm{C}_{36} \mathrm{H}_{50} \mathrm{~N}_{2} \mathrm{O}_{7}$ on the basis of high resolution ESI-MS $\left[(\mathrm{M}+\mathrm{H})^{+}, m / z 623.3794(-9.8 \mathrm{mmu}\right.$ error) $]$ in combination with ${ }^{1} \mathrm{H}$ and ${ }^{13} \mathrm{C}$ NMR data. The ${ }^{1} \mathrm{H}$ NMR and ${ }^{13} \mathrm{C}$ NMR

Table 2. ${ }^{1} \mathrm{H}$ and ${ }^{13} \mathrm{C}$ NMR spectral data of 1 and 2.

\begin{tabular}{|c|c|c|c|c|}
\hline \multirow{2}{*}{ No. } & \multicolumn{2}{|c|}{1} & \multicolumn{2}{|c|}{2} \\
\hline & $\delta_{\mathrm{H}}$ & $\delta_{\mathrm{C}}$ & $\delta_{\mathrm{H}}$ & $\delta_{\mathrm{C}}$ \\
\hline 1 & & $168.4 \mathrm{~s}$ & & $168.5 \mathrm{~s}$ \\
\hline 2 & $2.80,2.49$ & $44.0 \mathrm{t}$ & $2.61,2.75$ & $43.5 \mathrm{t}$ \\
\hline 3 & 4.09 & $79.1 \mathrm{~d}$ & 4.12 & $78.5 \mathrm{~d}$ \\
\hline 4 & 5.58 & $130.7 \mathrm{~d}$ & 5.62 & $130.6 \mathrm{~d}$ \\
\hline 5 & 6.28 & $134.5 \mathrm{~d}$ & 6.25 & $133.5 \mathrm{~d}$ \\
\hline 6 & 6.12 & $128.7 \mathrm{~d}$ & 6.00 & $129.3 \mathrm{~d}$ \\
\hline 7 & 6.14 & $134.8 \mathrm{~d}$ & 6.00 & $134.1 \mathrm{~d}$ \\
\hline 8 & 6.04 & $132.7 \mathrm{~d}$ & 6.05 & $133.4 \mathrm{~d}$ \\
\hline 9 & 5.84 & $131.2 \mathrm{~d}$ & 5.57 & $129.4 \mathrm{~d}$ \\
\hline 10 & $2.53,2.27$ & $36.4 \mathrm{t}$ & $2.52,2.33$ & $33.1 \mathrm{t}$ \\
\hline 11 & 3.63 & $71.0 \mathrm{~d}$ & 4.93 & $75.5 \mathrm{~d}$ \\
\hline 12 & 1.86 & $40.5 \mathrm{~d}$ & 1.86 & $39.6 \mathrm{~d}$ \\
\hline 13 & 5.92 & $75.0 \mathrm{~d}$ & 4.62 & $68.4 \mathrm{~d}$ \\
\hline 14 & & $134.0 \mathrm{~s}$ & & $138.6 \mathrm{~s}$ \\
\hline 15 & 5.23 & $126.4 \mathrm{~d}$ & 5.20 & $124.7 \mathrm{~d}$ \\
\hline 16 & $2.02,2.41$ & $29.0 \mathrm{t}$ & $2.20,1.97$ & $29.3 \mathrm{t}$ \\
\hline 17 & $2.55,2.39$ & $35.8 \mathrm{t}$ & 2.46 & $36.2 \mathrm{t}$ \\
\hline 18 & & $143.7 \mathrm{~s}$ & & $144.1 \mathrm{~s}$ \\
\hline 19 & 6.24 & $111.1 \mathrm{~d}$ & 6.20 & $110.8 \mathrm{~d}$ \\
\hline 20 & & $138.2 \mathrm{~s}$ & & $138.4 \mathrm{~s}$ \\
\hline 21 & 7.36 & $105.6 \mathrm{~d}$ & 7.50 & $105.7 \mathrm{~d}$ \\
\hline 22 & & $157.0 \mathrm{~s}$ & & $157.2 \mathrm{~s}$ \\
\hline 23 & 6.45 & $112.0 \mathrm{~d}$ & 6.50 & $111.9 \mathrm{~d}$ \\
\hline 24 & 0.88 & $10.6 \mathrm{q}$ & 0.93 & $9.8 \mathrm{q}$ \\
\hline 25 & 1.67 & $20.7 q$ & 1.80 & $20.3 \mathrm{q}$ \\
\hline 26 & 3.36 & $56.7 \mathrm{q}$ & 3.40 & $56.8 \mathrm{q}$ \\
\hline 27 & & $173.5 \mathrm{~s}$ & & $172.9 \mathrm{~s}$ \\
\hline 28 & 4.43 & $48.5 \mathrm{~d}$ & 4.41 & $48.5 \mathrm{~d}$ \\
\hline 29 & 1.40 & $17.5 q$ & 1.34 & $17.8 \mathrm{q}$ \\
\hline 30 & & $176.7 \mathrm{~s}$ & & $176.6 \mathrm{~s}$ \\
\hline 31 & 2.12 & $44.7 \mathrm{~d}$ & 2.12 & $45.1 \mathrm{~d}$ \\
\hline 32 & 1.44 & $29.8 \mathrm{t}^{\mathrm{a}}$ & 1.41 & $29.5 \mathrm{t}^{\mathrm{a}}$ \\
\hline 33 & $1.85,1.33$ & $25.6 \mathrm{t}^{\mathrm{b}}$ & $1.89,1.21$ & $25.6 \mathrm{t}^{\mathrm{b}}$ \\
\hline 34 & $1.81,1.67$ & $25.5 \mathrm{t}$ & $1.77,1.66$ & $25.5 \mathrm{t}$ \\
\hline 35 & $1.85,1.33$ & $25.6 \mathrm{t}^{\mathrm{b}}$ & $1.89,1.21$ & $25.7 \mathrm{t}^{\mathrm{b}}$ \\
\hline 36 & 1.44 & $29.0 \mathrm{t}^{\mathrm{a}}$ & 1.41 & $29.7 \mathrm{t}^{\mathrm{a}}$ \\
\hline
\end{tabular}

a-b Assignments interchangeable.

The spectra of 1 and 2 were recorded at $600 \mathrm{MHz}$ for ${ }^{1} \mathrm{H}$ and at $150 \mathrm{MHz}$ for ${ }^{13} \mathrm{C}$ in $\mathrm{CDCl}_{3}$.

The assignments were aided by ${ }^{1} \mathrm{H}-{ }^{1} \mathrm{H}$ COSY, DEPT, HMQC, $\mathrm{HMBC}$, and NOESY. 
Fig. 2. ${ }^{1} \mathrm{H}-{ }^{1} \mathrm{H}$ COSY, NOE and $\mathrm{HMBC}$ data of $\mathbf{1}$.

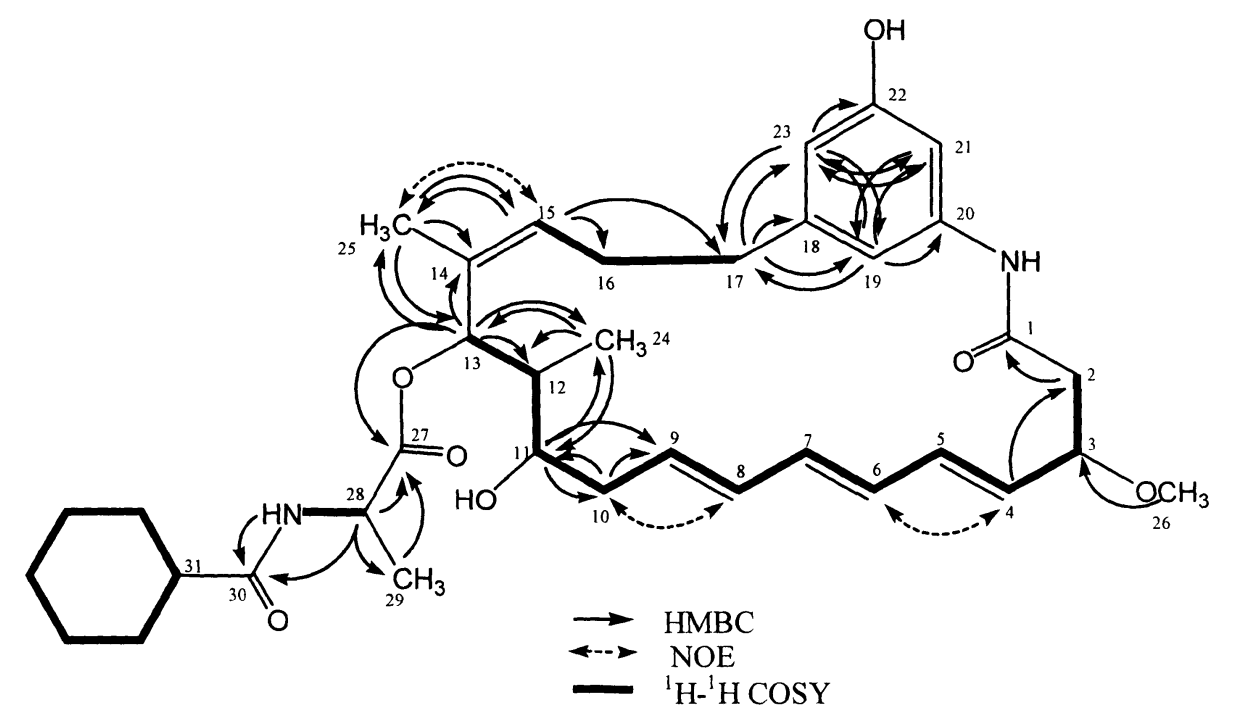

spectral data (Table 2) of 1 were very similar to those of the coisolated 2. The ${ }^{13} \mathrm{C}$ NMR assignments (Table 2) of the coisolated 2 were established independently in this study which were in a good agreement with the reported data ${ }^{18)}$ of 2. The ${ }^{1} \mathrm{H}$ NMR assignments (Table 2) of the coisolated 2 were first reported in this study. The major differences between 1 and 2 in ${ }^{1} \mathrm{H}$ and ${ }^{13} \mathrm{C}$ NMR data (Table 2) with HMQC data were that the methine signal $\left(\delta_{\mathrm{H}} 4.93(1 \mathrm{H}, \mathrm{td})\right.$ and $\left.\delta_{\mathrm{C}} 75.5\right)$ of C-11 in 2 was upfield-shifted to $\delta_{\mathrm{H}} 3.63$ and $\delta_{\mathrm{C}} 71.0$, respectively, in 1 while the methine signal $\left(\delta_{\mathrm{H}}\right.$ $4.62(1 \mathrm{H}, \mathrm{d})$ and $\left.\delta_{\mathrm{C}} 68.4\right)$ of $\mathrm{C}-13$ in 2 was downfieldshifted to $\delta_{\mathrm{H}} 5.92$ and $\delta_{\mathrm{C}} 75.0$, respectively, in 1. From these spectral data, it was speculated that the $\mathrm{N}$-hexahydrobenzoylalanine moiety may be linked to C-13 in 1 instead of $\mathrm{C}-11$ of 2 . The linkage position of the $N$-hexahydrobenzoylalanine moiety was determined by HMBC experiments (Fig. 2). Long range couplings were observed from the methine proton at $\delta_{\mathrm{H}} 5.92(\mathrm{H}-13)$ to $\mathrm{C}$ $12, \mathrm{C}-14, \mathrm{C}-24$, and $\mathrm{C}-25$, and from the methine proton at $\delta_{\mathrm{H}} 3.63(\mathrm{H}-11)$ to $\mathrm{C}-9, \mathrm{C}-10$, and $\mathrm{C}-24$. Also, long range couplings were observed from the $\alpha$-proton at $\delta_{\mathrm{H}} 4.43(\mathrm{H}$ 28 ) of alanine to $\mathrm{C}-27, \mathrm{C}-29$, and $\mathrm{C}-30$. The methine proton at $\delta_{\mathrm{H}} 5.92(\mathrm{H}-13)$, not $\delta_{\mathrm{H}} 3.63(\mathrm{H}-11)$, was long range coupled to the carbonyl carbon at $\delta_{\mathrm{C}} 173.5$ (C-27) of alanine in the $N$-hexahydrobenzoylalanine moiety. These spectral data indicated that the $N$-hexahydrobenzoylalanine moiety should be linked to $\mathrm{C}-13$. The remaining structure of 1 was also confirmed by ${ }^{1} \mathrm{H}-{ }^{1} \mathrm{H}$ COSY, $\mathrm{HMBC}$ and NOESY spectral data (Fig. 2). Thus the structure of 1 was determined as shown in Fig. 1.

$\mathbf{1}$ is a structural isomer of $\mathbf{2}$, differing by the linkage position of the $N$-hexahydrobenzoylalanine side chain to the ansa moiety. 2, a benzoid ansamycin antibiotic closely related to mycotrienins, was reported to have a potent cytocidal and cytotoxic activity ${ }^{19)}$. The relative and absolute stereochemistry of $\mathbf{2}$ have been elucidated by chemical analysis $^{20)}$.

1 and 2 exhibited the potent inhibitory effect on NO production in BV-2 microglia cells stimulated with LPS. The production of NO was assessed as the accumulation of nitrite in the culture supernatants using a coloricmetric reaction with the Griess reagent ${ }^{21)} .1$ and 2 inhibited dosedependently NO production in LPS-stimulated BV-2 cells with $\mathrm{EC}_{50}(\mathrm{nM})$ values of 292.3 and 25.4 , respectively as shown in Fig. 3A. This result showed that the position of the $N$-hexahydrobenzoylalanine moiety effected the activity. To see whether the observed inhibitory activity of $\mathbf{1}$ and $\mathbf{2}$ on NO production was due to a general effect on cell viability, the effect of $\mathbf{1}$ and $\mathbf{2}$ on cell viability was evaluated by MTS assay. 1 and $\mathbf{2}$ showed cytotoxic activity with $\mathrm{IC}_{50}(\mathrm{nM})$ values of 6274 and 1244 , respectively, which were 21 and 49 times, respectively, higher than those of their inhibitory activity on NO production (Fig. 3B). The inhibitory activity of $\mathbf{1}$ and $\mathbf{2}$ on NO production was well separated from their cytotoxic activity, suggesting that the inhibitory activity of $\mathbf{1}$ and $\mathbf{2}$ on NO production may not be due to the loss of cell viability. The inhibitory mechanism of $\mathbf{1}$ and $\mathbf{2}$ is under investigation. 
Fig. 3. The inhibitory activity on NO production (A) and the cytotoxic activity (B) of 1 and 2 in BV-2 cells.

(A)

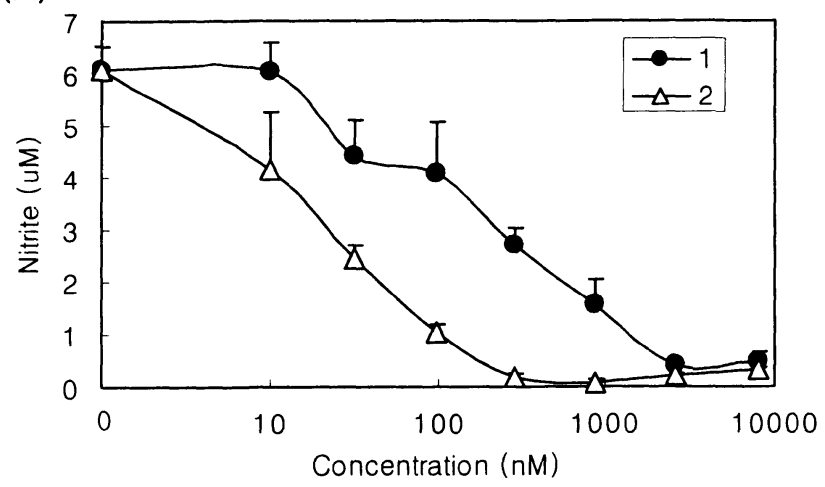

(B)

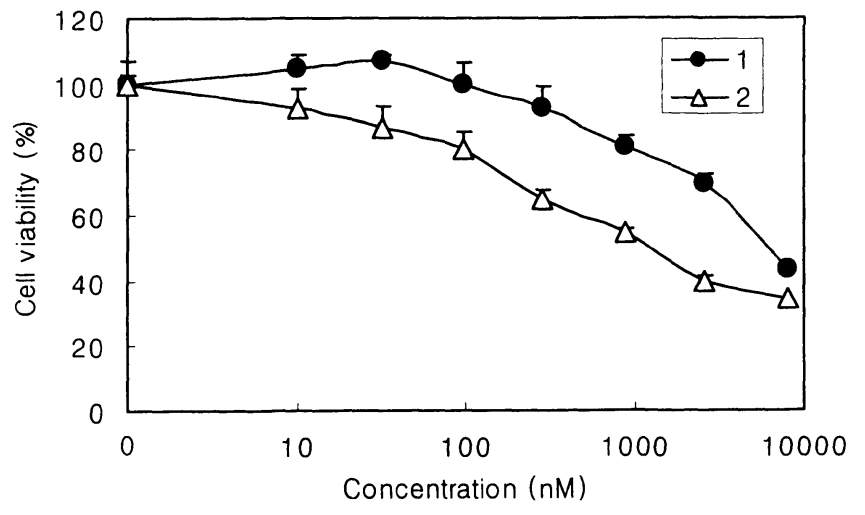

BV-2 cells were treated with vehicle (for the cytotoxic assay) or $1 \mu \mathrm{g} / \mathrm{ml}$ LPS (for the inhibitory assay on NO production) in the presence of the indicated concentrations of $\mathbf{1}$ and $\mathbf{2}$. The accumulation of nitrite and cell viability were assessed 24 hours later. The data represent the mean \pm S.E. of three wells.

\section{References}

1) Nathan, C. \& Q. W. XIE: Maloney: Nitric oxide synthases: roles, tolls, and controls. Cell 78: 915 918, 1994

2) BREDT, D. S. \& S. H. SNyder: Nitric oxide: a physiologic messenger molecule. Annu. Rev. Biochem. 63: 175 195, 1994

3) Gross, S. S. \& M. S. Wolin: Nitric oxide: pathophysiological mechanisms. Annu. Rev. Physiol. 57: 737 769, 1995

4) Griffith, O. W. \& D. J. Stuehr: Nitric oxide synthases: properties and catalytic mechanism. Annu. Rev. Physiol. 57: 707 736, 1995

5) Marletta, M. A.: Nitric oxide synthase: aspects concerning structure and catalysis. Cell 78: 927 930,
1994

6) NATHAN, C.: Inducible nitric oxide synthase: what difference does it make? J. Clin. Invest. 100: 2417 2423, 1997

7) Amin, A. R. \& S. B. Abramson: The role of nitric oxide in articular cartilage breakdown in osteoarthritis. Curr. Opin. Rheumatol. 10: 263 268, 1988

8) BRENDAN, J. R. W.: Role of iNOS in gut inflammatory and injury. Drug News Perspect 12: 157 164, 1999

9) Vodovotz, Y.; M. S. Lucia, K. C. Flanders, L. Chesler, Q.-W. Xie, T. W. Smith, J. Weidner, R. Mumford, R. Webber, C. Nathan, A. B. Roberts, C. F. LIPPA \& M. B. SPORN: Inducible nitric oxide synthase in tangle-bearing neurons of patients with Alzheimer's disease. J. Exp. Med. 184: 1425 1433, 1996

10) Parkinson, J. F.; B. Mitrovic \& J. E. Merrill: The role of nitric oxide in multiple sclerosis. J. Mol. Med. 75: $174 \sim 186,1997$

11) Gonzalez-Scarano, F. \& G. Baltuch: Microglial as mediators of inflammatory and degenerative diseases. Annu. Rev. Neurosci. 22: 219 240, 1999

12) ZiElASEK, J. \& H.-P. HARTUNG: Molecular mechanisms of microglial activation. Adv. Neuroimmunol. 6: 191 222, 1996

13) Kim, W.-G.; R. P. Mohney, B. Wilson, G.-H. Jeohn, B. LIU \& J.-S. HonG: Regional difference in susceptibility to lipopolysaccharide-induced neurotoxicity in the rat brain: role of microglia. J. Neurosci. 20: 6309 6316, 2000

14) JEOHN, G.-H.; W.-G. KIM \& J.-S. Hong: Time dependency of the action of nitric oxide in lipopolysaccharide-interferon- $\gamma$-induced neuronal cell death in murine primary neuron-glia cultures. Brain Research. 2000. 880(1-2): 173 177, 2000

15) Hobbs, A. J.; A. Higgs \& S. Moncada: Inhibition of nitric oxide synthase as a potential therapeutic target. Annu. Rev. Pharmacol. Toxicol. 39: 191 220, 1999

16) Chabrier, P-E.; C. Demerle-Pallardy \& M. Auguet: Nitric oxide synthases: targets for therapeutic strategies in neurological diseases. CMLS Cell. Mol. Life Sci. 55: 1029 1035, 1999

17) Alvi, K. A.; D. D. Baker, V. Stienecker, M. Hosken \& B. G. NAIR: Identification of inhibitors of inducible nitric oxide synthase from microbial extracts. J. Antibiotics 53: 496 501, 2000

18) Funayama, S.; K. OKada, K. Komiyama \& I. Umezawa: Structure of trienomycin A, a novel cytocidal ansamycin antibiotic. J. Antibiotics 38: 1107 1109, 1985

19) Funayama, S.; K. OKada, K. IWASAKI, K. Komiyama \& I. UMEZAWA: Structures of trienomycin A, B and C, novel cytocidal ansamycin antibiotics. J. Antibiotics 38: $1677 \sim 1683,1985$

20) SMith, A. B., III; J. L. Wood, W. Wong, A. E. Gould, C. J. Rizzo, J. Barbosa, K. Komiyama \& S. OMUra: (+)-Trienomycins A, B, C, and F and (+)-mycotrienins I and II: relative and absolute stereochemistry. J. Am. Chem. Soc. 118: 8308 8315, 1996

21) Green, L. C.; D. A. Wagner, J. Glogowski, P. L. SKIPPER, J. S. WishnoK \& S. R. TANNEnBaUm: Analysis of nitrate, nitrite, and $\left[{ }^{15} \mathrm{~N}\right]$ nitrate in biological fluids. Anal. Biochem. 126: 131 138, 1982 